Supporting information

\title{
Magnetic Relaxation Switch Biosensors Based on Self-Assembly of Polystyrene Microspheres and Magnetic Nanoparticles for Detection of Bisphenol A
}

Lei Huang ${ }^{a, b}, \dot{t}$, Sha Liu ${ }^{a, t}$, Shuyue Ren ${ }^{a}$, Man Zhang ${ }^{a, b}$, Tao Wang ${ }^{a, b}$, Xin Wang ${ }^{b, *}$, Zhixian Gao ${ }^{a}$ *

aTianjin Key Laboratory of Risk Assessment and Control Technology for Environment and Food Safety, Tianjin Institute of Environmental and Operational Medicine, Tianjin 300050, China.

bShool of Medical Instrument and Food Engineering, University of Shanghai for Science and Technology, Shanghai 200093, China.

*Corresponding Author

E-mail: 18918629281@126.com (Xin Wang);

gaozhx@163.com (Zhixian Gao). 


\section{Table of Contents}

\section{Materials, Apparatus, Methods}

Figure S1. The relaxivity coefficient $\left(r_{2}\right)$ of magnetic particles (MNPs).

Figure S2. The fluorescence spectroscopy of "Apt (FAM)", “Apt (FAM) + cDNABHQ1", and "Apt (FAM) + cDNA-BHQ1+BPA".

Figure S3. Circular dichroism characterizes changes in aptamer structure.

Figure S4. Optimization of probe preparation conditions.

Figure S5. Quantification of Apt and cDNA concentration.

Figure S6. Condition optimization of the PS-MRS sensor.

Figure S7. Measurements of the reproducibility of the PS-MRS sensor.

Figure S8. Molecular structures of BPA, TBPA, BP, BPC, BPB, and 6F-BPA.

Figure S9. The HPLC linear fitting curve between the concentration of BPA and its peak area.

Table S1. Sequences of oligonucleotides used in this study.

Table S2. Comparison of our assay with traditional assay for the detection of BPA. 


\section{Materials}

Carboxylic acid-functionalized magnetic nanoparticles $\left(\mathrm{MNP}_{20}-\mathrm{COOH}\right)(20 \mathrm{~nm}$, solid content: $4 \mathrm{mg} / \mathrm{mL}$ ) and carboxylic acid-functionalized polystyrene microspheres $\left(\mathrm{PS}_{1000}-\mathrm{COOH}\right),(1000 \mathrm{~nm}$, solid content: $50 \mathrm{mg} / \mathrm{mL})$ were purchased from Beijing zhongkeleiming daojin technology Co., Ltd (Beijing, China). Bisphenol A $\left(\mathrm{C}_{15} \mathrm{H}_{16} \mathrm{O}_{2}\right.$, BPA), 1-ethyl-3-(3-dimethylaminopropyl) carbodiimide hydrochloride $\left(\mathrm{C}_{8} \mathrm{H}_{17} \mathrm{~N}_{3} . \mathrm{HCl}\right.$, EDC), N-Hydroxysuccinimide $\left(\mathrm{C}_{4} \mathrm{H}_{5} \mathrm{NO}_{3}\right.$, NHS) purchased from Sigma-Aldrich (Shanghai, China). 3, 3', 5, 5'-Tetrabromobisphenol A $\left(\mathrm{C}_{15} \mathrm{H}_{12} \mathrm{Br}_{4} \mathrm{O}_{2}\right.$, TBBPA), 4, 4'-(Hexafluoroisopropylidene) diphenol $\left(\mathrm{C}_{15} \mathrm{H}_{10} \mathrm{~F}_{6} \mathrm{O}_{2}\right.$, 6F-BPA), 2, 2-Bis (4-hydroxyph-enyl) butane $\left(\mathrm{C}_{16} \mathrm{H}_{18} \mathrm{O}_{2}, \mathrm{BPB}\right), 2$, 2-Bis (4-hydroxy-3-methylphenyl) propane $\left(\mathrm{C}_{17} \mathrm{H}_{20} \mathrm{O}_{2}\right.$, BPC), 4, 4'-Dih-ydroxydiphenyl $\left(\mathrm{C}_{12} \mathrm{H}_{10} \mathrm{O}_{2}\right.$, BP) were purchased from Shanghai yuanye Bio-Technology Co., Ltd (Shanghai, China). PBS buffer (10 mM, $\mathrm{pH}=7.4)$, MES buffer $(100 \mathrm{mM}, \mathrm{pH}=6.0,0.5 \mathrm{M} \mathrm{NaCl})$ and Binding buffer $(25 \mathrm{mM}$ Tris$\mathrm{HCl}, \mathrm{pH}=8.0,100 \mathrm{mM} \mathrm{NaCl}, 25 \mathrm{mM} \mathrm{KCl}, 10 \mathrm{mM} \mathrm{MgCl}_{2}$ ) were of analytical grade and prepared in deionized water produced by a Millipore Milli-Q (18.3 M $\Omega$ ). $0.22 \mu \mathrm{m}$ and $0.45 \mu \mathrm{m}$ membrane filters were purchased from Merck KGaA (Darmstadt, Germany). Besides, the PC bottle was purchased from a local Supermarket and the real water sample was obtained from Haihe River (Tianjin, China). All oligonucleotides used in this study (Table S1) were synthesized and purified by Sangon Biotech (Shanghai, China).

\section{Apparatus}

Magnetic relaxation characteristics were determined on a $0.467 \mathrm{~T}$ NMR instrument 
(PQ-001, Suzhou niumag analytical instrument corporation, China). The SEM images were obtained on SEM (ZEISS MERLIN COMPACT). The samples were scattered on the silicon wafer and then measured at followed parameters $(\mathrm{EHT}=10.00 \mathrm{kV}$; WD $=9.0$ $\mathrm{nm})$. The background of SEM images is silicon wafer. Fluorescence spectrophotometer (F97pro, Shanghai Lengguang Technology Co., Ltd., China). Magnetic separation rack (DynaMagTM-2 Magnet, Thermo Fisher Scientific, USA). Thermo shaker incubator (TMS-200, Hangzhou Allsheng Instruments Co., Ltd., China). High performance liquid chromatography (HPLC) (Waters Alliance-2695, Waters, USA). Circular dichroic spectrometer (CD) (J-815, JASCO Co., Japan).

\section{Methods}

\subsection{Preparation of $\mathrm{MNP}_{20}-\mathrm{Apt}$ and $\mathrm{MNP}_{20}-\mathrm{cDNA}$}

A $100 \mu \mathrm{L}$ of $\mathrm{MNP}_{20}-\mathrm{COOH}(1 \mathrm{mg} / \mathrm{mL})$ solution was added into a centrifuge tube $(1.5 \mathrm{~mL})$ and separated by a Magnetic separation rack at $15 \mathrm{~min}$. Then mixed with 100 $\mu \mathrm{L}$ of EDC (40 mM), $100 \mu \mathrm{L}$ of NHS (100 mM), and $300 \mu \mathrm{L}$ of MES buffer $(0.1 \mathrm{M}$, $\mathrm{pH}=6.0,0.5 \mathrm{M} \mathrm{NaCl}$ ) to react for $15 \mathrm{~min}$ and removed the supernatant again by Magnetic separation rack at $15 \mathrm{~min}$. Followed by added $200 \mu \mathrm{L}$ of amino-modified aptamer (Apt$\left.\mathrm{NH}_{2}\right)$ or amino modified-complementary DNA (cDNA- $\left.\mathrm{NH}_{2}\right)(4 \mu \mathrm{M}$, dissolved in PBS buffer) solution, and shook in a Thermo shaker incubator for 2 hours at $37^{\circ} \mathrm{C}$. After magnetic separation at 15 min and washing three times with Binding buffer, the $\mathrm{MNP}_{20}-$ Apt or $\mathrm{MNP}_{20}-\mathrm{cDNA}$ could be obtained. Then, it was re-suspended with $200 \mu \mathrm{L}$ of Binding buffer and stored at $4{ }^{\circ} \mathrm{C}$. 


\subsection{Preparation of $P S_{1000}-A p t$}

Added $500 \mu \mathrm{L}$ of $\mathrm{PS}_{1000}-\mathrm{COOH}(1 \mathrm{mg} / \mathrm{mL})$ solution into a centrifuge tube $(1.5 \mathrm{~mL})$, and remove the supernatant after centrifugal separation at $5000 \mathrm{r} / \mathrm{min}$ for $4 \mathrm{~min}$. Then added $100 \mu \mathrm{L}$ of EDC $(40 \mathrm{mM}), 100 \mu \mathrm{L}$ of NHS $(100 \mathrm{mM})$, and $300 \mu \mathrm{L}$ of MES buffer $(0.1 \mathrm{M}, \mathrm{pH}=6.0,0.5 \mathrm{M} \mathrm{NaCl})$, shook for 15 minutes and removed the supernatant at $15000 \mathrm{r} / \mathrm{min}$ for 4 minutes. Followed by added $200 \mu \mathrm{L}$ of Apt $-\mathrm{NH}_{2}(5 \mu \mathrm{M}$, dissolved in PBS buffer) solution, and shook in a Thermo shaker incubator for $2 \mathrm{~h}$ at $37^{\circ} \mathrm{C}$. After centrifugal separation at $15000 \mathrm{r} / \mathrm{min}$ for $4 \mathrm{~min}$ and washing three times with Binding buffer, the aptamer-functionalized polystyrene microspheres $\left(\mathrm{PS}_{1000}-\mathrm{Apt}\right)$ were re-suspended with $1 \mathrm{~mL}$ of Binding buffer and stored at $4^{\circ} \mathrm{C}$.

\subsection{LF-NMR relaxation measurement parameters}

The related parameters of LF-NMR: spectral width (SW) is $125 \mathrm{kHz}$; RF $90^{\circ}$ pulse width (P1) and RF $180^{\circ}$ pulse width (P2) are $7 \mu$ s and $14 \mu$ s, respectively; recycle time is $2000 \mathrm{~ms}$; number of scans (NS) is 4; number of echoes is 10000; echo time $(\tau)$ is $1 \mathrm{~ms}$. The principle of the CPMG pulse sequence is to use a $90^{\circ} \mathrm{RF}$ pulse in the $\mathrm{X}$-axis direction, followed by the echo time and a series of $180^{\circ} \mathrm{RF}$ pulses in the $\mathrm{Y}$-axis direction. The $T_{2}$ decay curve can be formed by recording the echo signal strength of the echo time after the $180^{\circ} \mathrm{RF}$ pulse ${ }^{1}$. If we assume that there is only one hydrogen proton state in the sample, the mono-exponential component fitting is used to reflect the average value of the relaxation time in the entire sample, that is, the single-component relaxation 
time $\left(\mathrm{T}_{2 \mathrm{~W}}\right)^{2}$. It is defined as equivalent to $67 \%$ of the time required for the maximum signal decay ${ }^{3}$.

\subsection{Verification of the principle of PS-MRS sensor}

The feasibility of the proposed method was investigated. We added $50 \mu \mathrm{L}$ of Apt (FAM) and $200 \mu \mathrm{L}$ of binding buffer into a centrifuge tube $(0.5 \mathrm{~mL})$ as a control group. Then, added $50 \mu \mathrm{L}$ of Apt (FAM), $50 \mu \mathrm{L}$ of cDNA-BHQ1, $125 \mu \mathrm{L}$ of Binding buffer, and $25 \mu \mathrm{L}$ of different concentrations of $\mathrm{BPA}(0,0.1,1,10 \mathrm{ng} / \mathrm{mL})$ into centrifuge tube $(0.5$ $\mathrm{mL})$ as an experimental group. Finally, the fluorescence values were examined after incubation at $37{ }^{\circ} \mathrm{C}$ for $120 \mathrm{~min}$. Besides, we also investigated the $\mathrm{T}_{2 \mathrm{~W}}$ of $\mathrm{PS}_{1000}-\mathrm{Apt}-$ cDNA-MNP ${ }_{20}$ conjugate. We added $100 \mu \mathrm{L}$ of $\mathrm{MNP}_{20}-\mathrm{cDNA}(50 \mu \mathrm{g} / \mathrm{mL})$ into $100 \mu \mathrm{L}$ of Binding buffer as " $\mathrm{MNP}_{20}-\mathrm{cDNA}$ " group, added $100 \mu \mathrm{L}$ of $\mathrm{MNP}_{20}-\mathrm{cDNA}(50 \mu \mathrm{g} / \mathrm{mL})$ into $100 \mu \mathrm{L}$ of $\mathrm{PS}_{1000}(100 \mu \mathrm{g} / \mathrm{mL})$ as " $\mathrm{MNP}_{20}-\mathrm{cDNA}+\mathrm{PS}_{1000}$ " group and added $100 \mu \mathrm{L}$ of $\mathrm{MNP}_{20}$-cDNA $(50 \mu \mathrm{g} / \mathrm{mL})$ into $100 \mu \mathrm{L}$ of $\mathrm{PS}_{1000}-\mathrm{Apt}(100 \mu \mathrm{g} / \mathrm{mL})$ as "MNP${ }_{20}$ cDNA+PS ${ }_{1000}-\mathrm{Apt}^{\prime \prime}$ group. Finally, their $\mathrm{T}_{2 \mathrm{~W}}$ values were examined after incubation at $37^{\circ} \mathrm{C}$ for $120 \mathrm{~min}$.

\subsection{Reproducibility of the PS-MRS sensor}

The reproducibility measurements were performed on the two PS-MRS sensors. They were prepared from two different batches with the same conditions. The $T_{2 W}$ signals of these PS-MRS sensors of two different batches were measured for 20 times, respectively. The PS-MRS sensors of were incubated with 20 parallel BPA solutions (50 $\mathrm{ng} / \mathrm{mL}), \mathrm{T}_{2 \mathrm{~W}}$ signals of which were then recorded and measured three times. 


\subsection{HPLC for the detection of BPA}

The process of HPLC for detection of BPA according to Chinese standard (GB/T 23296.16-2009). Briefly, the preparation of BPA standards at different concentrations $(0.1,1,10,100,1000 \mathrm{ng} / \mathrm{mL})$ using methanol as a solution, and the measurement conditions as follows:

a) Chromatographic column: $\mathrm{C}_{18}$ column (Column length=250 mm, Inner diameter $=4.6 \mathrm{~mm}$, Particle size $=5 \mu \mathrm{m})$.

b) Mobile phase: methanol/water $=70 / 30$.

c) Flow rate: $1 \mathrm{~mL} / \mathrm{min}$.

d) Column temperature: room temperature.

e) Fluorescence detector: excitation wavelength $(E x)=227 \mathrm{~nm}$; emission wavelength $(\mathrm{Em})=313 \mathrm{~nm}$.

\subsection{LOD and Selectivity of the assay}

The limit of detection (LOD) is defined as the lowest concentration of components of the sample that could be tested, which is calculated as follows:

$$
L O D=\frac{K S_{\text {b1 }}}{S}
$$

$\mathrm{K}=$ the constant of confidence level $(\mathrm{K}=3)$;

$\mathrm{S}_{\mathrm{b} 1}=$ the standard deviation of $\mathrm{T}_{2 \mathrm{~W}}$ value in an aqueous solution of test probe $(\mathrm{n}=20)$;

$\mathrm{S}=$ the slope of the linear region of the curve.

In the selectivity test, several analogs $(\mathrm{BPC}, \mathrm{BPB}, \mathrm{BP}, \mathrm{TBBPA}, 6 \mathrm{~F}-\mathrm{BPA}$, and their mixture (MIX), $500 \mathrm{ng} / \mathrm{mL}$ ) were employed to test the selectivity for the detection of 
BPA $(50 \mathrm{ng} / \mathrm{mL})$.

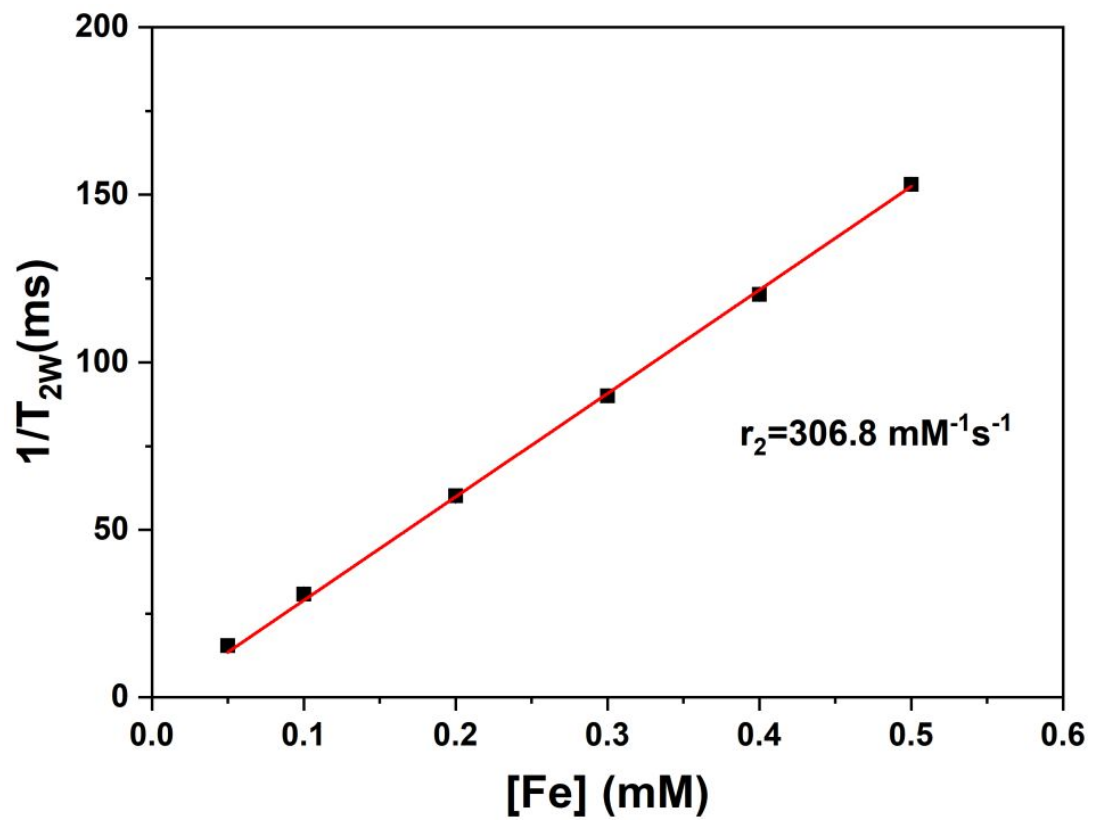

Figure S1. The relaxivity coefficient $\left(r_{2}\right)$ of magnetic particles (MNPs).

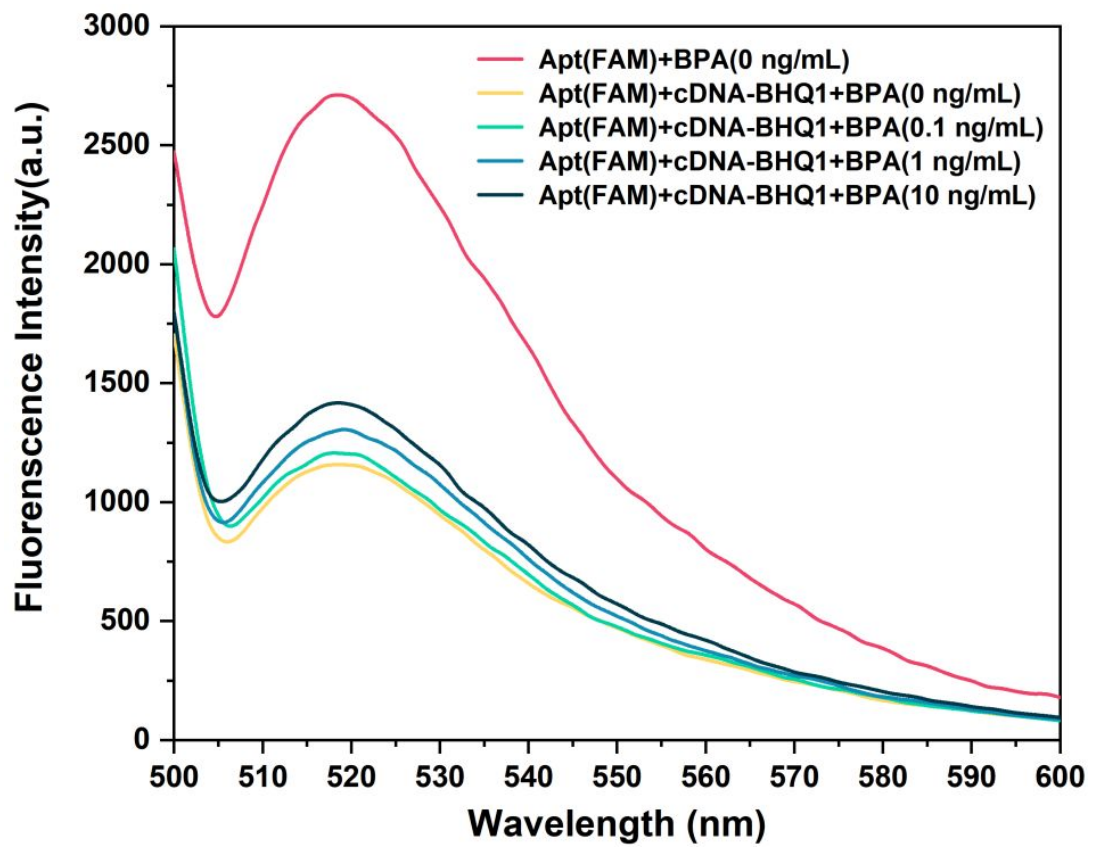

Figure S2. The fluorescence spectroscopy of "Apt (FAM)", "Apt (FAM) + cDNABHQ1", and "Apt (FAM) + cDNA-BHQ1+BPA". 


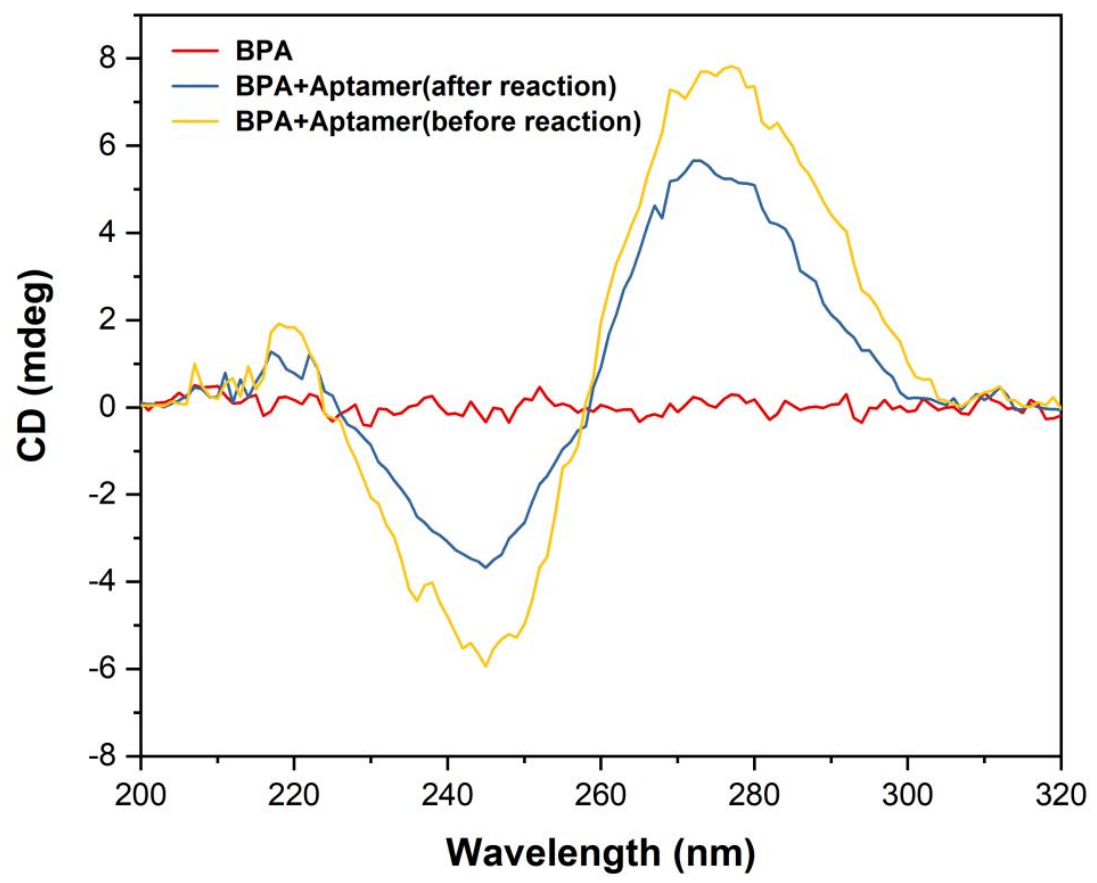

Figure S3. Circular dichroism characterizes changes in aptamer structure. 

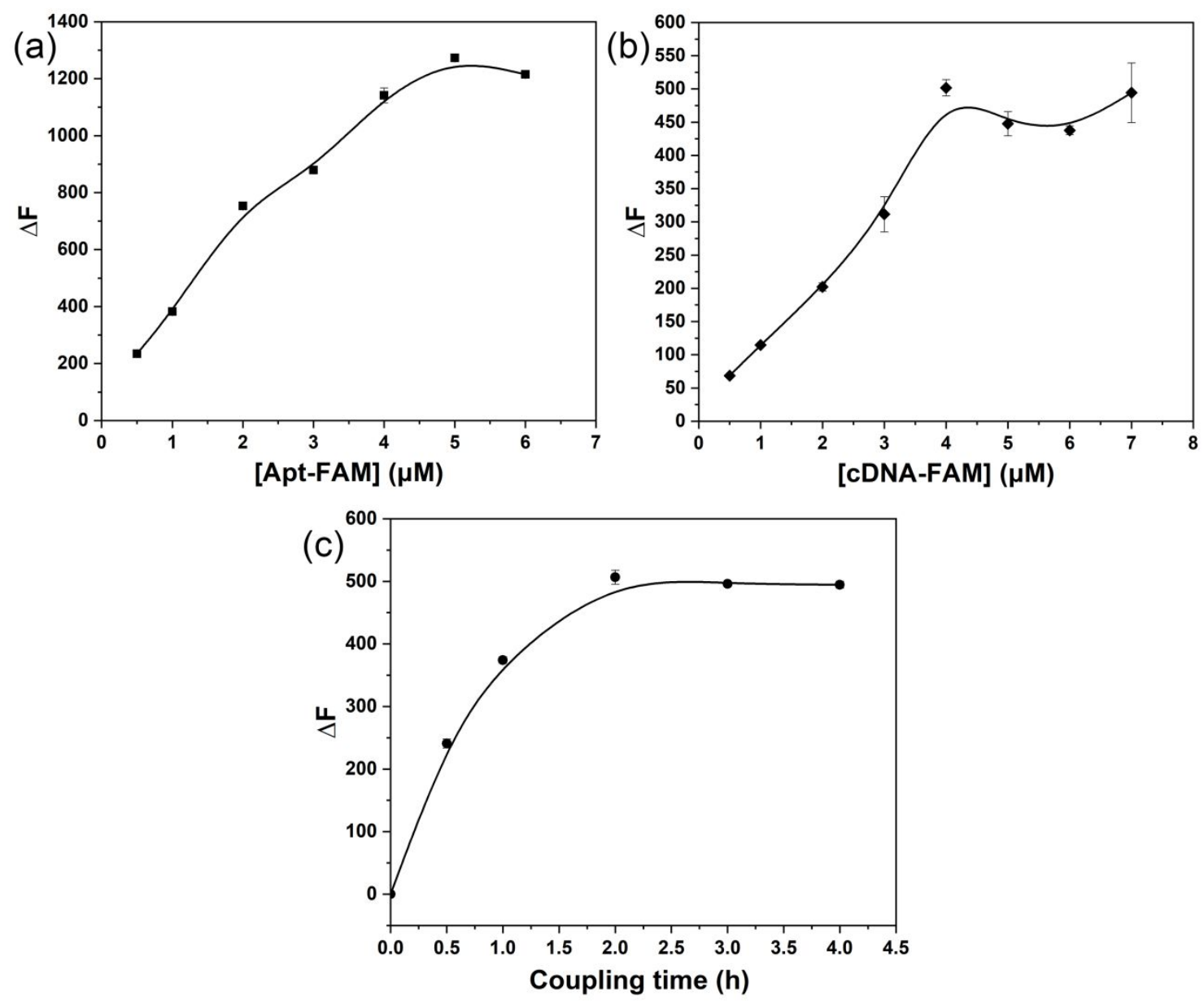

Figure S4. Optimization of probe preparation conditions. (a) The effect of Apt-FAM concentrations on the preparation of $\mathrm{PS}_{1000}-\mathrm{Apt}$ (or $\mathrm{MNP}_{20}-\mathrm{Apt}$ ) probe. (b) The effect of cDNA-FAM concentrations on the preparation of $\mathrm{MNP}_{20}-\mathrm{cDNA}$ probe. (c) The coupling time on the probe preparation was determined by fluorescence spectrophotometer. 

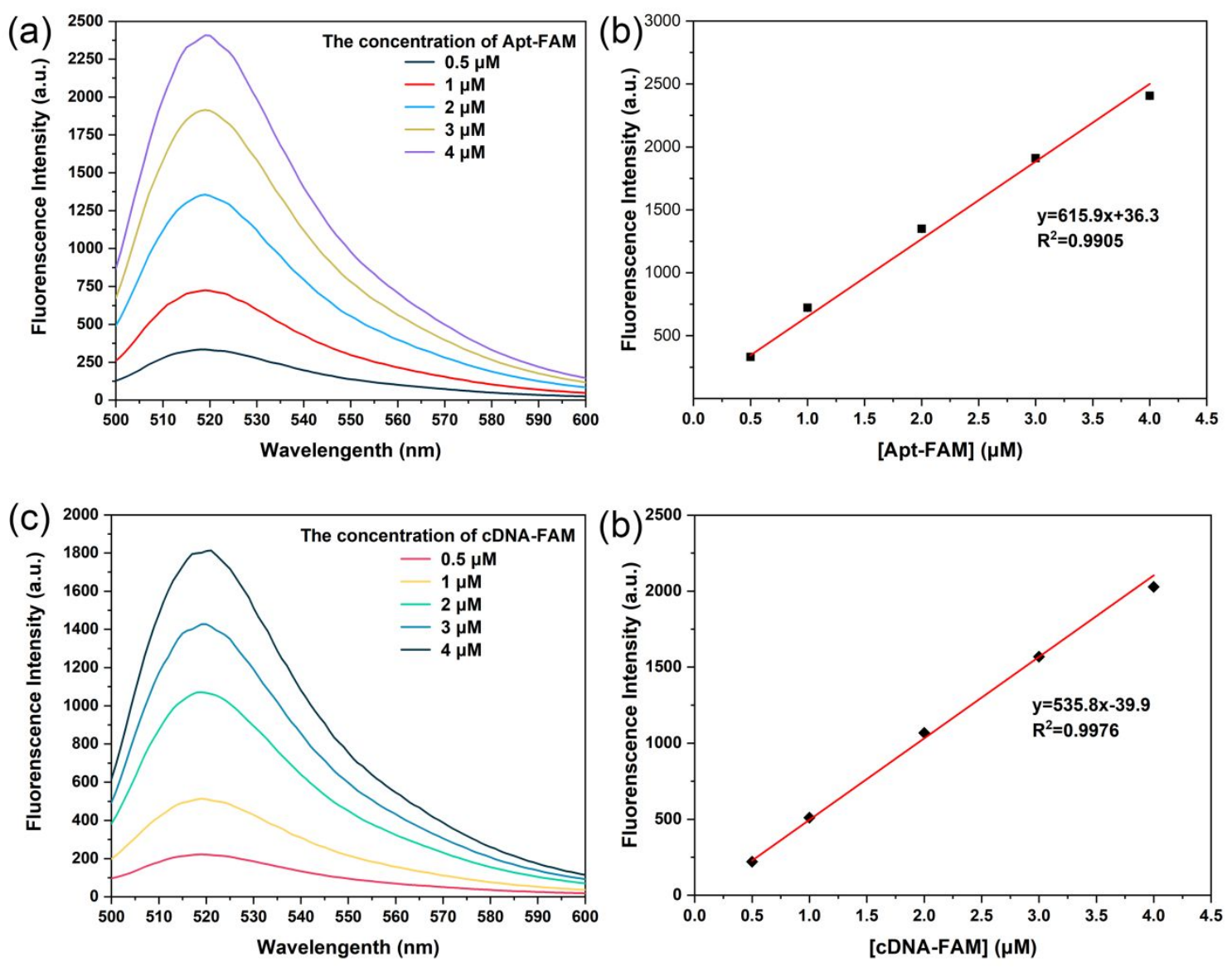

Figure S5. Quantification of Apt and cDNA concentration. (a) The fluorescence spectroscopy of different concentration of Apt-FAM. (b)The linear fitting curve between the fluorescence value of Apt-FAM at $520 \mathrm{~nm}$ and its concentration. (c) The fluorescence spectroscopy of different concentration of DNA-FAM. (d) The linear fitting curve between the fluorescence value of cDNA-FAM at $520 \mathrm{~nm}$ and its concentration. 

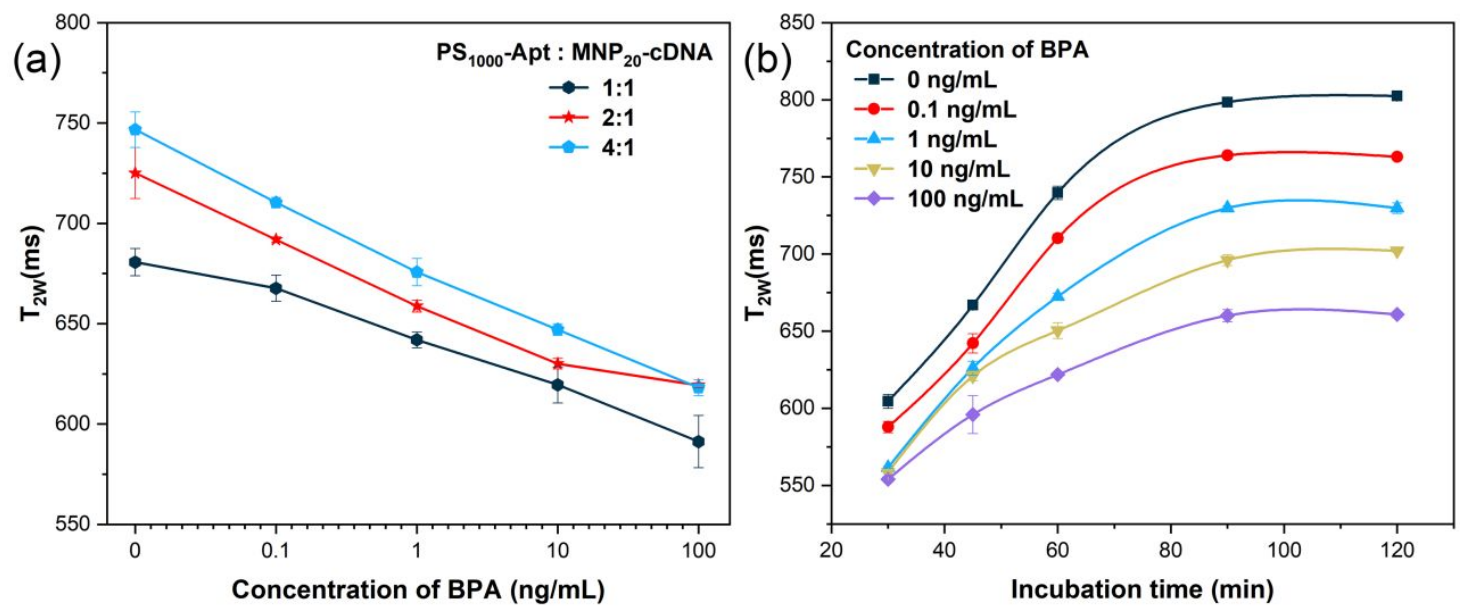

Figure S6. Condition optimization of the PS-MRS sensor. (a) Effect of the concentration ratio of $\mathrm{PS}_{1000}-\mathrm{Apt}$ and $\mathrm{MNP}_{20}-\mathrm{cDNA}$ on $\mathrm{T}_{2 \mathrm{w}}$. (b) Effect of the different incubation time on $\mathrm{T}_{2 \mathrm{~W}}$.

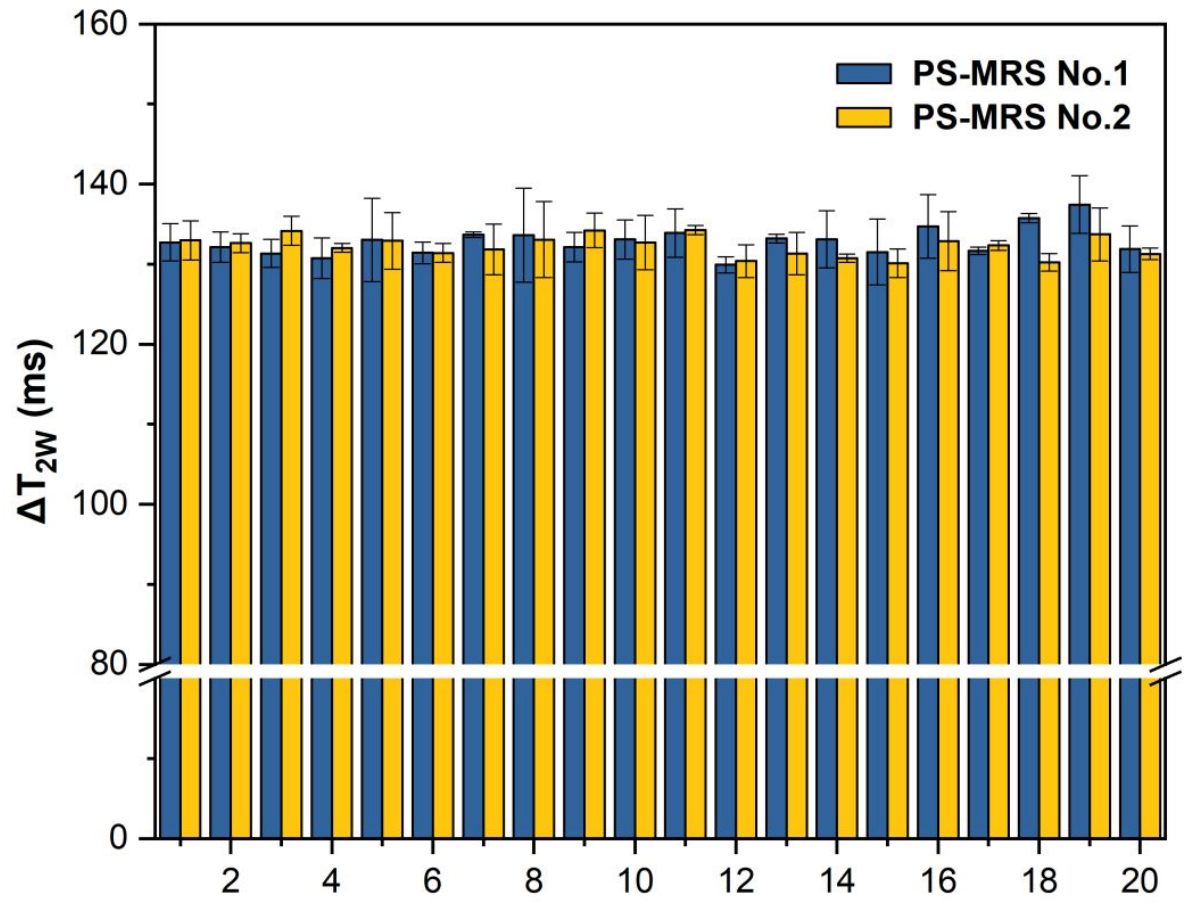

Figure S7. Measurements of the reproducibility of the PS-MRS sensors. The changes of $\mathrm{T}_{2 \mathrm{~W}}$ signal $\left(\Delta \mathrm{T}_{2 \mathrm{~W}}\right)$ for the 20 parallel BPA solution $(50 \mathrm{ng} / \mathrm{mL})$ were performed on two different batches of PS-MRS sensors. 
<smiles>CC(C)(c1ccc(O)cc1)c1ccc(O)cc1</smiles>

BisphenolA (BPA)<smiles>Oc1ccc(-c2ccc(O)cc2)cc1</smiles>

4, 4'-Dihydroxydiphenyl (BP)<smiles>CCC(C)(c1ccc(O)cc1)c1ccc(O)cc1</smiles>

2-Bis (4-hydroxyphenyl) butane (BPB)<smiles>CC(C)(c1cc(Br)c(O)c(Br)c1)c1cc(Br)c(O)c(Br)c1</smiles>

3, 3', 5, 5'-TetrabromobisphenolA (TBBPA)<smiles>Cc1cc(C(C)(C)c2ccc(O)c(C)c2)ccc1O</smiles>

2, 2'-Bis (4-hydroxy-3-methylpheny) propane (BPC)

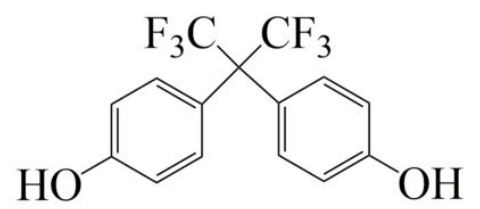

4, 4'- (Hexafluoroisopropylidene) diphenol (6F-BPA)

Figure S8. Molecular structures of BPA, TBPA, BP, BPC, BPB, and 6F-BPA. 


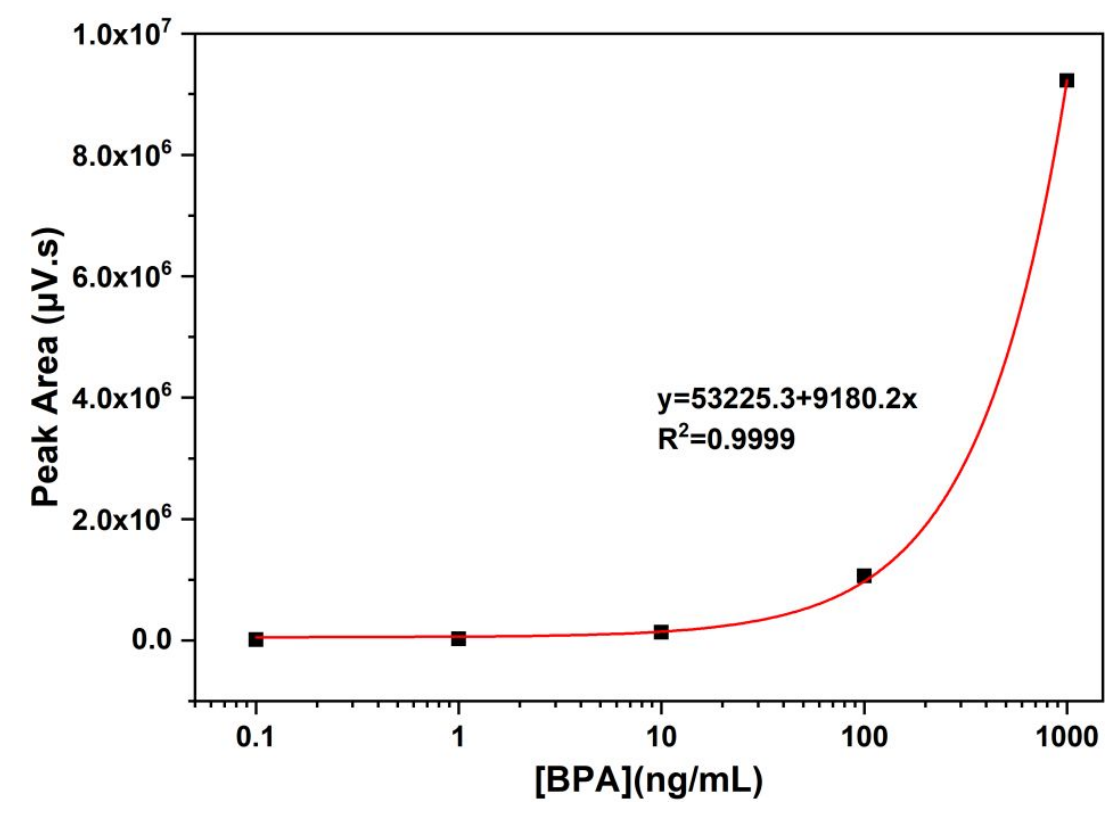

Figure S9. The HPLC linear fitting curve between the concentration of BPA and its peak area.

Table S1. Sequences of oligonucleotides used in this study

\begin{tabular}{|c|c|}
\hline Name & Sequence \\
\hline $\begin{array}{l}\text { Anti-BPA } \\
\text { aptamer }\end{array}$ & $\begin{array}{c}\text { 5'-NH }{ }_{2}-\mathrm{T}_{10} \text {-CCGGTGGGTCAGGTGGGATAGCGTTCCGCG } \\
\text { TATGGCCCAGCGCATCACGGGTTCGCACCA-3' }\end{array}$ \\
\hline Apt-FAM & $\begin{array}{c}\text { 5'-NH}{ }_{2}-\mathrm{T}_{10} \text {-CCGGTGGGTCAGGTGGGATAGCGTTCCGCG } \\
\text { TATGGCCCAGCGCATCACGGGTTCGCACCA-FAM-3' }\end{array}$ \\
\hline Apt (FAM) & $\begin{array}{l}\text { 5'-CCGGTGGGTGGTCAGGTG/i6FAMdT/GGATAGCGTTC } \\
\text { CGCGTATGGCCCAGCGCATCACGGGTTCGCACCA-3' }\end{array}$ \\
\hline cDNA & 5 '- $\mathrm{NH}_{2}-\mathrm{T}_{10}$-ATACGCGGAACGCTA-3' \\
\hline cDNA-FAM & 5'-NH ${ }_{2}-\mathrm{T}_{10}$-ATACGCGGAACGCTA-FAM-3' \\
\hline cDNA-BHQ1 & 5'-ATACGCGGAACGCTA-BHQ1-3' \\
\hline
\end{tabular}

Note: cDNA is partly complementary to the anti-BPA aptamer sequence in bold. 
Table S2. Comparison of our assay with traditional assay for the detection of BPA

\begin{tabular}{|c|c|c|c|c|c|}
\hline Assays & $\begin{array}{c}\text { LOD } \\
(\mathrm{pmol} / \mathrm{L})\end{array}$ & $\begin{array}{c}\text { Estimated Cost } \\
(\text { dollar })\end{array}$ & $\begin{array}{c}\text { Time } \\
\text { Consumption } \\
(\mathrm{min})\end{array}$ & Real sample & Reference \\
\hline LC/MS & 3.5 & 30 & 180 & Fish & 4 \\
\hline ELISA & $2.2 \times 10^{2}$ & 10 & 120 & Water & 6 \\
\hline LNDH/MRS & $0.3 \times 10^{3}$ & - & 120 & Water & 7 \\
\hline MRS & $0.1 \times 10^{5}$ & 2.5 & 30 & PC bottle; Water & This Work \\
\hline PS-MRS & $0.3 \times 10^{3}$ & 1.5 & 95 & & \\
\hline
\end{tabular}

\section{REFERENCES}

(1) Li, T.; Rui, X.; Tu, C.; Li, W.; Wang, K.; Huang, L.; Dong, M. NMR Relaxometry and Imaging to Study Water Dynamics during Soaking and Blanching of Soybean. Int. J. Food Eng. 2016, 12 (2), 181-188, DOI: 10.1515/ijfe-2015-0166.

(2) Wang, C.; Su, G.; Wang, X.; Nie, S. J. J. o. A. Rapid Assessment of Deep Frying Oil Quality as Well as Water and Fat Contents in French Fries by Low-Field Nuclear Magnetic Resonance. J. Agric. Food Chem. 2019, 67 (8), 2361-2368.

(3) Hansen, C. L.; Thybo, A. K.; Bertram, H. C.; Viereck, N.; van den Berg, F.; Engelsen, S. B. Determination of dry matter content in potato tubers by low-field nuclear magnetic resonance (LF-NMR). J. Agric. Food Chem. 2010, 58 (19), 10300-4, DOI: 10.1021/jf101319q. 
(4) Chen, W. L.; Wang, G. S.; Gwo, J. C.; Chen, C. Y. Ultra-high performance liquid chromatography/tandem mass spectrometry determination of feminizing chemicals in river water, sediment and tissue pretreated using disk-type solid-phase extraction and matrix solid-phase dispersion. Talanta 2012, 89, 237-45, DOI: 10.1016/j.talanta.2011.12.020.

(5) Ju, C.; Xiong, Y.; Gao, A.; Yang, T.; Wang, L. Development of a Direct Competitive Enzyme-linked Immunosorbent Assay Using a Sensitive Monoclonal Antibody for Bisphenol A. Hybridoma 2011, 30 (1), 95-100, DOI: 10.1089/hyb.2010.0079.

(6) Wang, J. Y.; Guo, Q. Y.; Yao, Z. Y.; Yin, N.; Ren, S. Y.; Li, Y.; Li, S.; Peng, Y.; Bai, J. L.; Ning, B. A.; Liang, J.; Gao, Z. X. A low-field nuclear magnetic resonance DNA-hydrogel nanoprobe for bisphenol A determination in drinking water. Microchim. Acta 2020, 187 (6), 333, DOI: 10.1007/s00604-020-04307-6.

(7) Huang, L.; Wang, X. Rapid and sensitive detection of Bisphenol A in water by LF-NMR based on magnetic relaxation switch sensor. Microchem. J. 2021, 163, 105911, DOI: 10.1016/j.microc.2020.105911. 